\title{
THE CONSEPT AND ITS IMPLEMENTATION OF INDONESIAN \\ LEGISLATIVE ELECTIONS BASED ON THE PANCASILA DEMOCRACY PERSPECTIVE
}

\author{
Franciscus Xaverius Wartoyo \\ Lecturer STKIP PGRI Sidoarjo \\ E-mail:yoyokwartoyo97@gmail.com
}

\begin{abstract}
Indonesia's democracy system was built on the basis and the strength of Pancasila, which did not favor the excessive desires of individual negotiations (liberalism) neither absolute state domination, non-liberalism, namely direct and indirect democracy that was once practiced. Those forms have their own weaknesses, but this paper will only highlight the positive side of the open democratic system, sincerely the democratic system of this nation is Pancasila democracy which refers to those two major forces of democracy. The implementation of Pancasila's democracy in the Legislative Election can be shown in Law Number 7 of 2017 on the General Elections 2019 in Indonesia. The history of the implementation of elections in Indonesia revealed a variety of dynamics indicated by several changes in the constitutional law which were used as the basis for the implementation of elections. The publication of the Election Law is the elaboration of the provisions of Article 22E of the 1945 Indonesian Constitution. This means that the principles of democracy contained within 1945 Constitution of the Republic of Indonesia, must become the main foundations in designing norms in Law Number 7 of 2017 on the General Elections 2019, as happened, it turns out that the parliamentary threshold regulation within the Constitutional Law are ineffective in implementing this democracy.
\end{abstract}

Key Word: characteristics, democracy, election.

\section{A. INTRODUCTION}

Democracy's reformation era was such an abstract and universal concept. Those kinds of democracy has been applied in many countries in various forms, which results in various titles, such as constitutional democracy, peoples democracy, guided democracy, liberal democracy, and so on. One of democracy's systemwhich has been practiced in Indonesia is constitutional democracy. It's adjusted regulationsare explicitly stated in article 1 paragraph 2 of the 1945 Constitution amendments (also known as the 1945 Constitution of the Republic of Indonesia) which states that sovereignty is in the hands of the people and carried out according based on the constitution (Tim Grasindo, 2017: 60-62).

Yustisia Volume 8 Number 1 (January-April 2019)

The Consept And Its

(C)2019; This is an Open Acces Research distributed under the term of the Creative Commons Attribution Licencee (https://Creativecommons.org/licences/by/4.0), which permits unrestricted use, distribution, and reproduction in any medium, provided the original works is properly cited. 
Indonesia's democracy system was built on the basis and the strength of Pancasila, which did not favor the excessive desires of individual negotiations (liberalism) neither absolute state domination, non-liberalism, namely direct and indirect democracy that was once practiced before. Both forms have their own weaknesses, but this paper will only highlight the positive side of the open democratic system, sincerely the democratic system of this nation is Pancasila democracy which refers to those two major forces of democracy.

One of platforms that was made for realizing the implementation of democracry was general election. The general election's itself has been held since 1955 until 2014 which during its regulations process, experiencing various of dynamics. The election which held in 2009 was reffering to Law Number 7 of 2017 on the General Elections 2019, concerning the election of the member of House of Representatives (hereinafter named as $D P R$ ), Regional Representative Councils (Hereinafter named as $D P D$ ), and Regional People's Represntative Assembly (Hereinafter named as $D P R D$ ). Whereas in Law Number 7 of 2017 on the General Elections 2019, it is directed in order to emphasize the principles of democracy, and also strengthen the presidential government system in order to create effective governmental system. The affirmation of the principles of democracy both directly and indirectly appears in legal norms that accommodate the determination of elected members based on the majority of votes.

The changes from indirect democracy to direct democracy has brought implication to decision making's mechanism in general election in Indonesia, prior to where general election are done by people voting for their president candidate, house of representative did the vote. Law Number 7 of 2017 on the General Elections 2019 said, that the number of seats for $D P R$ are 560 ( five hundreds and sixty). Article 22 paragraph 1 also said, that $D P R$ 's electoral district consist of province, town/district, or town and district combined. Paragraph 2 also said, that number of seats for each $D P R$ 's electoral district are at minimum 3 seats, and maximum 10 seats. Article 413 Law Number 7 of 2017 on the General Elections 2019 stated, that the number of seats for DPRD province level are set at minimum 35 (thirty five) and maximum 100 (one hundred). While Article 26 paragraph 1 stated, the number of the seats for $D P R D$ town/district are set minimum 20(twenty) and maximum 50(fifty).

Article 182 Law Number 7 of 2017 on the General Elections 2019 stated, that the number of the seats for $D P D$ for each province are set at minimum 4 (four). Article 182 paragraph 2 stated, the election for member of $D P D$ is implemented with a district electoral system with many candidates. Therefore, legislative election are using 2 system, which are the open proportional system, and district electoral system with many candidates. 
The concept of state law are not meant to be separated from the ideology of the democracy it self (I Dewa Gede Atmadja, 2015: 45), sincerely because state law is one of the true concept of democratic country, and the meaning of democratic itself is the safest forms of controlling in execution matters of state law (democratic state law).The basic idea of state law is that the implementation of state law should be able to be carried out as well as possible, that is in accordance with the expectations of the law and just (because the basic purpose of the law is justice).According the understanding of state law's concept in substantial, According to the understanding of the concept of the state law in content, the spirit of democracy based on a legal perspective, results in two views, which are related to tangible rules of how to get power and how to exercise power (Hastuti, Sri P., Jurnal Hukum: FH UII, Volume 3 Number 6, 1996: 101).

The democracy's characteristic as already made and determined in Article 1 paragraph 2 and legal sovereignty (nomocracy), are regulated in Article 1 paragraph 31945 Indonesian Constitution. Each of those clause has a specific connection of availability that cannot be separated in a country that has a democratic system and respects the status quo of law and justice, like Indonesia. The democratic process has a goal to emphasize justice in the implementation of politics. Besides, democracy can be also as a sourcefor creating the fifth principle of Pancasila, which also can affect in political sphere, in the fields of economics and other fields. As democracy in the economic field can be economic democracy, as well in the political field can be called political democracy, so that if it is attached to the electoral system, then political democracy should be based on the basis of state law, namely Pancasila and the 1945 Constitution can be called Pancasila democracy. As in the old order regime political democracy and economic democracy were called socio-democracy.

\section{B. PROBLEM STATEMENT}

Based on the results of the preliminary explanation above, the author specificallyfocused on to how Pancasila democracy was manifested in the implementation of the legislative elections in Indonesia?

\section{RESEARCH METHODS}

The research is a normative legal research (doctrinal research). It used a qualitative analysis and legislation approaches. Thus, the choice of relevant material and integrated interpretation during interviews with stakeholders related to the main research issues. 


\section{DISCUSSION AND RESEARCH RESULT}

Since Law Number 7 of 2017 on The General Elections 2019 are officially valid as guidance of The Prseident and Vice President, DPR RI, DPD, DPRD Elections and Head of district, and applies for election's guidance, thus the election's event name officially changes to General election for Head and Vice Head of District. As stated in Law Number 10 of 2016 on The Local Leader Elections, candidates that can be chosen in election are those who proposed by political parties or coalition of multiple political parties. This regulations has been replaced by Law Number 7 of 2017 on The General Elections that states, the candidates that can be chosen in regional head election, are those who propose him/herself independently, without any affiliation from political parties. The changes mark the further action from Constitutional Court's ruling. The decision to eliminate some articles regarding the chosen candidate based on Law Number 10 of 2016 on The Local Leader Elections which followed by some eliminations and revision on articles that stated in Law Number 9 of 2015 on The Local Government. Particularly in Nanggroe Aceh Darusalam, the chosen candidate can be proposed by local political parties. Therefore, there are consequences reside within the constitutional system by the changes in the democratic system and nomocracy as stated in the foundation of the state of the Republic of Indonesia.

Before the amendment of 1945 Constitution, People's Consultative Assembly (MPR) was the highest state institution. After the amendment, the constitutional position of the MPR is similar to other high institutions among the House of Representatives (DPR), the Supreme Audit Agency (BPK), the Constitutional Court, the President, and the Supreme Court (MA). One of it's obligation is to appoint and dismiss the chosen president and or vice president based on election results, as stated in Law Number 7 of 2017 on The General Elections

.The institution that organizes the election of members of the House of Representative of the Republic of Indonesia (DPR RI), the Regional Representative Council (DPD) and the Regional Representative Council (DPRD), and the election of the president and vice president and regional head elections is carried out by the General Election Commissions (KPU), which is an independent institution and not tied to government influence. Prior to Law Number 12 of 2003 on The Elections, general election is held by Ministry of Home Affairs. After the exercising of Law Number 12 of 2003, the general election is held by General Election Commissions (KPU). The outgrowth of the regulations that affect democracy system in this country are not merely derived from state rules but also rule of law, also in aspect substantive principles of justice that are extracted from the general norms of society by judges. The statement of Indonesia is the state law can be seen in article 1 paragraph (3) of the 1945 Constitution, which unites between the rules of the state and the rule of law. The constitution as a common foundation for the nation and state which ultimately 
embodies the 1945 Constitution. The 1945 Constitution acts as a source of legal order, giving meaning that the acts and implementation of laws and regulations must not be contradictive to The 1945 Constitution which also can even be used as a guideline for regulating a regulation product.

As a state law, Indonesia has a few foundations as follow: 1) supremacy of law, which regulated in Article 1 paragraph 31945 Constitution; 2) Equality before the law , which also regulated in Article 27 paragraph 11945 Constitution, and 3) due process law which regulated in Article 241945 Constitution. The principle of state law which adopted by Indonesia is "The State Law in accordance with Pancasila"that is conical and integrative, namely a state law that unites good elements from a number of different concepts (rechtsstaat, the rule of law, as well as formal and material legal concepts) and given Indonesian values (such as family, fatherhood, harmony, balance and deliberation are the fundamental basis of the Indonesian legal culture) so that it becomes the principle of the "State of the Pancasila Law" (Kartayasa Mansur, 2017: 158-159).

The responsibility as a legal state, changes that are important to be carried out canarise to an obligation for the state to carry out fair provisions. The principle of justice in the rule of law has a commitment to become a "middle ground between two interests", giving the government the freedom to carry out government duties with its power, but on the other hand the community must get protection for their rights through the principle of legal justice which is Pancasila. Indonesia as a legal state in the article of the 1945 Constitution strengthens the status quo of the 1945 Constitution as a state constitution that must be maintained and enforced, this is the role of the judicial institution namely the constitutional court in upholding the constitution (Indonesian Constitution 1945) also should be in the conduct of general elections with the principle of legal justice which is Pancasila.

The characteristics of democracy are clearly contained in The 1945 Constitution of the Republic of Indonesia. From the opening up to the article and the verses clearly contained the conception of the People's Sovereignty. In the fourth chapter of the Preamble of the 1945 Constitution, it was stated: “... and popularism led by wisdom of wisdom in consultation / representation, and by realizing a social justice for all Indonesian people". The principle of peoples sovereignty is also stated in Article 1 paragraph (2) of the 1945 Indonesian Constitution which explains: "Sovereignty is in the hands of the people and carried out according to the Constitution". The principle of peoples sovereignty is also seen in all the mechanisms and procedures contained in the 1945 Indonesian Constitution. Starting from the procedures for political recruitment, power, legislation, taxation and elections reflect that the 1945 Constitution is guided by the notion of peoples sovereignty with representative concept.

Law Number 7 of 2017 on The General Elections as an expansion of Article 22E 1945 Constitution, has given a clear direction regarding the implementation of peoples 
sovereignty in Indonesia. The fundamentals understanding of people sovereignty as stated in Article 1 paragraph 21945 Constitution, undergoing a special meaning in the regulation as stated in Law Number 7 of 2017 on The General Elections, even though it has also been decided by the Constitutional Court through decision Number 52/P/UU-X/2012 until it can be concluded that Law Number 7 of 2017 does not reflect the principle of free democracy (Kurniawan G, Jurnal Inovatif, Vol. VIII No. 1. 2015: 70-72), but still bases on Pancasila in addition to the 1945 Constitution.

Pancasila democracy, in the sense of democracy that has patterns of implementation in accordance with the reality and ideals contained in this nation's society, requires more guidance so that it becomes a political culture full of vitality. It is also absolutely necessary to liberate the dynamics found in society with various forces that support Pancasila. Therefore, freedom is needed in carrying out extensive political activities, but still has limitations within the boundaries of values of Pancasila. The issue of human rights as one of main issue for political parties for the coming year must be reviewed in order to achieve a balance between open and closed democracy and between direct and indirect democracy called Pancasila democracy.

The principles of Pancasila Democracy absorb the basic principles of democracy (both direct and indirect and closed or open), which are freedom, equality, social justice, openness and recognition of diversity in social life. Among the principles of Pancasila democracy are freedom and equality in expressing opinions. In Indonesia the freedom of expressing opinions are guaranteed in the constitution, stated in Article 28 of the 1945 Constitution which states "Freedom of association and assembly, conveying thoughts both oral and written". The meaning of this sentence is that Indonesian citizen are free to express their aspirations and guaranteed constitutionally. The desire to express opinions certainly must not conflict with applicable laws in Indonesia.

The 1945 Constitution of the Republic of Indonesia amendments, explicitly organizes elections which are specifically found in Chapter VII B concerning general elections, namely in Article $22 \mathrm{E}$ which determines that:

a. General election is carried out directly, publicly, freely, secretly, honestly and fairly in every five years;

b. General election are held to choose member of $D P R, D P D, D P R D$, President and Vice President;

c. Participants in the general election to elect members of the House of Representatives (DPR) and Members of the Regional People's Legislative Assembly (DPRD) are political parties;

d. Participants in the general election to elect members of the Regional Representative Council (DPD) are individuals; 
e. General elections are held by an electoral commission that is national, permanent, independent, and

f. Furthermore, the general election is regulated by constitution.

Article 6 A paragraph (1) of the 1945 Constitution stipulates that the president and vice president are elected in one pair of candidates directly by the people, the provisions are chosen directly by the people. In the field of philosophy contrary to the essence of the fourth principle of Pancasila " popularism is led by wisdom of wisdom in representative deliberation". This shows that the fourth principle of Pancasila emphasizes the principle of deliberation to reach consensus through its representatives and representative bodies in contending for the people's mandate. Hence, regarding to the general election of the president and vice president should be carried out by an official representative body that is a representation of the people of Indonesia, and not carried out by voting, as opposed to the four principles of the Pancasila.

For the next election for House of Representatives ahead, aside considering the implementation of district system using the single member district method as a direct election model, it can also compete healthily among candidates and be more democratic; without any element of mutual dependence on political party leaders. The implementation of this system is deemed suitable of forming a capable member of House of Representative and supported by its constituents. In addition, every citizen as the subject of the highest sovereignty has the right to make choices. Re-elect the previous elected president for the next five years or replace it with a new leader.

Likewise with direct elections, which filled with money politics, it is also one of the weaknesses of the current election mechanism. Requirements for prospective candidates that are quite difficult from the KPU, a candidate must spend a lot of money to increase the chance to be elected, especially for independent candidates. The position of political parties as political vehicles also creates a holethat can result in political dowry. It is recommended for legislative power institutions, that the law on political parties and elections does not change every five years, moreover the issuance of laws, relatively only one year before the voting day. This of course will greatly disrupt the KPU's readiness in preparing technical administration, so that it will greatly disrupt the quality of implementation and election results.

Based on the values contained in Pancasila democracy (Yusdianto, Jurnal Fiat Justisia, Volume 10 Number 2, Juni 2016: 115), as follows:

a. Freedom that is followed by responsibility for both the community, the nation, and the God of Almighty.

b. Uphold the dignity and human dignity.

c. Every Indonesian citizen has the same standing, rights and obligations before the law. 
d. Forcing your will onothers is forbidden.

e. Respect and uphold every decision made as a result of deliberation.

f. Recognizing differences and similarities as individuals among groups, races, ethnicities, religions.

g. During a forum, mutual interests and agreements must be prioritized above personalor group interests, and

h. Emphasizing justice in social life in order to achieve common goals.

Based on examination on point "e" above, "prioritizing deliberation in making joint decisions", the implementation of the presidential and vice presidential elections in Indonesia is approved in Article 6A of the 1945 Constitution and Law Number 7 of 2017 on the General Election of the President and Vice-President appointed directly, is not relevant with the values that exist in the Pancasila democracy which prioritizes consensus during deliberation.

\section{E. CLOSING}

\section{Conclusion}

The implementation of Pancasila democracy in the Legislative Election bases on Law Number 7 of 2017 on The General Elections for The President and Vice President, DPR, DPD, and DPRD in Indonesia carried out through general election. The history of elections in Indonesia shows a variety of dynamics which are indicated by several changes in laws that are used as the basis for the implementation of elections, until the last modification namely Law Number 7 of 2017. The publication of the Election Law is the elaboration of Article 22E of the 1945 Constitution. This means that the principles of democracy contained in the 1945 Constitution must become the main guideline in creating norms in Law Number 7 of 2017 on The General Elections, it turns out that the parliamentary threshold regulation that applied in constitutional law can be said that there is not really suitable in implementing this democracy.

\section{Suggestion}

The election for House of Representatives, should consider applying a district system (majority) with a single member district formula such as elections for Regional Representative Council (DPD) institutions so that there is healthy competition among candidates and be more democratic; without any element of dependence on the leader of political parties and should be able to eliminate the dowry system so that politicians will emerge who indeed have expert competence in their field. 


\section{BIBLIOGRAPHY:}

\section{Books:}

Asshiddiqie Jimly, 2009, Menuju Negara Hukum yang Demokratis (Towards a Nation of Law), Bhuana Ilmu Populer.

Atmadja, I Dewa Gede, 2015. Teori Konstitusi dan Konsep Negara Hukum (Constitutional Theory and The Concept of The Nation of Laws), Setara Press: Malang.

Bernard, Sidharta. A. 2011.Refleksi tentang Struktur Ilmu Hukum (Reflections on The Structure of Law), terjemahan dari JJH, Bruggink, Mandar Madju: Bandung.

Hans Kelsen, 2007. General Theory of Law and State, Bee Media Indonesia: Jakarta.

HendraHurtjahjo, 2005, Filfasat Demokrasi (Philosophy of Democracy), Jakarta: Pusat Studi Hukum Tata Negara Fakultas Hukum Universitas Indonesia.

HeriKusmanto dan TK. Brahmana, 2005, .Pemilu dan Harapan Demokrasi di Indonesia, Demokrasi dan Problematika Otonomi Daerah (Elections and Hopes of Democracy in Indonesia, Democracy and Problems in Regional Autonomy), Raja Grafindo Persada: Jakarta.

Kartayasa Mansur, 2017, Korupsi \& Pembuktian Terbalik dari Perspektif Kebijakan Legislasi dan Hak Asasi Manusia (Corruption and Reverse Verification from the Perspective of Legislation and Human Rights Policy), Kencana: Jakarta.

Tim Grasindo, 2017. UUD 1945 \& Amandemennya untuk Pelajar dan Umum (The 1945 Constitution of The Republic of Indonesia and Amendments for Students and Public), Gramedia Pustaka: Jakarta.

Tricahyo, Ibnu, 2009, Reformasi Pemilu Menuju Pemisahan Pemilu Nasional dan Lokal (Election Reform Towards Separation of The National and Local Elections), In-Trans Publishing: Malang.

\section{Journals:}

Hastuti, Sri P.,(1996), Kekuasaan dan Demokrasi, Jurnal Hukum: FH. UII, Volume 3 Number 6.

Kurniawan G. (2015), Kebebasan Sebagai Hakekat Demokrasi. Jurnal Inovatif, Volume VIII Number 1.

Yusdianto, (2016), Makna Filosofis Nilai-Nilai Sila Keempat Pancasila dalam Sistem Demokrasi di Indonesia. Jurnal Fiat Justisia, Vol. 10 No. 2.

Zulfirman, (2006), Ontologi Demokrasi, Jurnal Hukum, Volume 14 Number 2. 


\section{Regulations:}

The 1945 Constitution of The Republic of Indonesia

Law Number 7 of 2017 on The General Elections (State Gazette of The Republic of Indonesia Number 182 of 2017);

Law Number 10 of 2016 on The Local Leaders Election (State Gazette of The Republic Indonesia Number 130 of 2016) 